\title{
ЖИВОТНОВОДСТВО В ДОМАШНИХ ХОЗЯЙСТВАХ НАСЕЛЕНИЯ НИЗКОГОРЬЯ РЕСПУБЛИКИ АЛТАЙ ${ }^{1}$
}

\section{LIVESTOCK BREEDING IN HOUSEHOLDS OF THE POPULATION OF THE LOW MOUNTAINS OF THE ALTAI REPUBLIC E. Enchinov E. Torushev}

Summary: The livestock activity of the population of the low mountains of the Altai Republicis investigated in the article. The influence of nature and climate conditions on the livestock breeding of the local population is observed. The analysis of methods of cattle maintenance is given. The role of livestock products in the life support system of the population of the low mountains of the region is described.

Keywords: The Republic of Altai, low mountains, pasture and grazingmanagement, cows, horses, sheep, pigs, poultry, bees.

\author{
Енчинов Эркин Валериевич \\ К.и.н., С.н.с., БНУ РА «Научно-исследовательский \\ институт алтаистики им. С.С. Суразакова» \\ (2. Горно-Алтайск) \\ enchinov_e@mail.ru \\ торушев Эркем Геннадьевич \\ К.и.н., с.н.с., БНУ РА «Научно-исследовательский \\ институт алтаистики им. С.С. Суразакова» \\ (2. Горно-Алтайск) \\ erktor@mail.ru
}

Аннотация: В статье исследована животноводческая деятельность населения низкогорья Республики Алтай. Рассмотрено влияние природно-климатических условий на животноводство местного населения. Дан анализ способов содержания домашних животных. Описана роль животноводческой продукции в системе жизнеобеспечения населения низкогорья региона.

Ключевые слова: Республика Алтай, пастбищно-стойловое содержание, крупнорогатый скот, лошади, мелко-рогатый скот, свиньи, домашняя птица, пчелы.

научный оборот вводятся новые материалы этнографических экспедиций 2020-2021 гг.

Первые опубликованные сведения о животноводческой деятельности населения низкогорья Горного Алтая появляются в XIX в. Это работы Г. Гельмерсена, В.И. Вербицкого, В.В. Радлова, Н.М. Ядринцева и др. Исследователи отмечают, что у таежных алтайцев из занятий более развиты охотничий промысел и мотыжное земледелие. Авторы констатируют, что из-за значительного зимнего снежного покрова жители тайги вынуждены держать небольшое количество лошадей, коров и овец [3; 27: 2; 32]. В конце XIX в. С.П. Швецов по заданию правительства России собирает значительный материал по хозяйственной деятельности населения Горного Алтая. Собранный материал публикуется в 1900 г. в статистическом сборнике «Горный Алтай его население». В этой работе содержится обширная информация о количестве домашних животных, об их процентном соотношении по видовому составу и т.д. [30].

Весомый вклад в изучение истории и этнографии коренного населения Горного Алтая внесли советские ученные. Так, хозяйственную деятельность кумандинцев исследовал Ф.А. Сатлаев. Автор в монографии «Кумандинцы: историко-этнографический очерк XIX - первой четверти XX века» описал систему содержания скота,

Научная новизна исследования состоит в том, что в

Исследование осуществлено при финансовой поддержке РФФИ, проект № 20-49-040009 р_а 
структуру домашнего стада и т.д. [28].

В 1999 г. выходит из печати монография Е.П. Кандараковой «Обычаи и традиции чалканцев», где подробно описаны ритуальные действия чалканцев при отеле коров. Автор последовательно излагает ход обрядовых действий, начиная с того, как хозяева принимаются следить за коровой непосредственно перед отелом и какие ритуалы чалканцы совершали после рождения теленка [7, с. 162-166].

В 2000-х гг. публикуются монографии, в которых рассмотрены животноводческая деятельность населения низкогорья Горного Алтая. Одной из такой работой является академическое издание «Тюркские народы Сибири» [29]. Исследователем А.П. Макошевым в монографии «Вопросы территориальной организации горно-животноводческого хозяйства Алтая» веден большой научный материал по территориальной организации сельского хозяйства Республики Алтай. Также в работе проанализированы вопросы, связанные с эффективностью животноводства в разных типах природной среды региона, дается хозяйственная оценка природных условий, историко-географические особенности и экономические условия сельскохозяйственного производства Горного Алтая [8].

Животноводство кумандинцев рассмотрено в монографии И.И. Назарова «Кумандинцы: традиционное хозяйство и материальная культура» [25].

В 2014 г. из печати выходит коллективная монография «Алтайцы: Этническая история. Традиционная культура. Современное развитие», в работе анализу подвергается система скотоводства таежных алтайцев. В этом же 2014 г. публикуется другая монографическая работа Н.И. Шитовой «Русские низкогорной зоны Горного Алтая (20 - начало 21 вв.)». В исследовании автор, опираясь на анкеты Всероссийской сельскохозяйственной переписи 1917 г., а также другие архивные материалы, рассматривает животноводство русского населения низкогорья Горного Алтая за 1910-е и 1920-е гг. [31].

Животноводческая деятельность населения любого региона земного шара напрямую зависит от окружающей среды. Поэтому кратко опишем природно-климатические условия изучаемой территории. Регион низкогорья расположен в северо-западной части Республики Алтай и граничит на востоке с Республикой Хакассией, на севере с Кемеровской областью, на западе с Алтайским краем. Южные границы низкогорья проходят внутри Республики Алтай, на юго-востоке они граничат с Улаганским районом, на юге с Онгудайским районом, на юго-западе с Шебалинским и Чемальским районами.

Долины низкогорья Горного Алтая (долины рек Бии и нижней Катуни с их притоками) расположены на высоте 300-600 м над уровнем моря. Рельеф слабо расчленен, речные долины относительно широкие, сочетаются с гривами, вытянутыми в разных направлениях.

Климат изучаемой территории Горного Алтая можно охарактеризовать как резко-континентальный. Зимы многоснежные, высота снежного покрова во многих местах превышает более одного метра. Лето умеренно теплое.

Изучаемая территория по количеству выпадающих атмосферных осадков один из наиболее увлажненных мест Горного Алтая. В среднем выпадает 900-1000 мм осадков.

Растительность низкогорья произрастает на типичных, обыкновенных и оподзоленных черноземных почвах. Территории богаты лесами, которые образуют черневую тайгу с высокотравными лугами. Для такой тайги характерны преобладание хвойных деревьев (пихты, кедра, ели) и мелколиственных лесов (осинников, березовых чащ).

В этно/антропологическом плане, низкогорье Горного Алтая многонациональная территория. Согласно Всероссийской переписи 2010 г. в основном проживают русские (82,5\%) и коренные жители Республики Алтай (16,2\%). Изучаемый массив региона является местом компактного проживания таежных алтайцев, которые состоят из трех этнических групп: тубалары, чалканцы и кумандинцы. В настоящее время они имеют статус коренных малочисленных народов РФ [26, с. 23].

На исследуемых территориях традиционно были развиты лесные промыслы, земледелие, также жители низкогорья занимались и животноводством. Например, в 1897 г. на 100 жителей низкогорья приходилось - лошадей, КРС МРС - 254 условных голов в переводе на крупный (коэффициент перевода в условных голов в переводе на крупный: лошади - 1; КРС - 0,8; овцы и козы - 0,18; свиньи - 0,3 [8, с. 84]). Всего в 1897 г. население исследуемого региона держало КРС, лошадей и МРС общей численностью - 23,3 тыс. условных голов в переводе на крупный [8, с. 83-84].

В Советский период на изучаемой территории Горного Алтая кроме сельского хозяйства развиваются деревообрабатывающие предприятия, и налаживается добыча полезных ископаемых. В связи, с чем в исследуемых массивах региона начинается механический рост населения. В 1940 г. здесь на 100 жителей приходилось - 70 условных голов в переводе на крупных голов при общем численности основного вида скота 36,5 тыс. условных голов (основной вид скота - КРС, лошади и МРC [8, с. 84]). К концу существования Советского Союза в 1990 г. на 100 
жителей низкогорья приходилось - 71 условных голов при общей численности основного вида скота - 32,2 тыс. условных голов скота [8, с. 83-84].

В 1990-х гг. в Российской Федерации происходит реорганизация колхозов и совхозов эти процессы существенно уменьшили количество домашних животных в Республике Алтай. Например, в 2000 г. в низкогорье Республики Алтай основного вида скота было - 14,9 тыс. условных голов, на 100 жителей приходилось 31 условных голов основного вида скота [8, с. 83-84]. То есть за десятилетие 1990-х гг. численность КРС, лошадей и МРС уменьшилось более чем в два раза.

В 2010-х гг. как и в предшествующие периоды, животноводство остается отраслью влияющей на жизнеобеспечение жителей изучаемых территорий. Например, в 2019 г. население Турачакского, Чойсккого и Майминского районов составили 55214 чел., они выращивали КРС - 9198 голов, в том числе коров - 3941 голов, лошадей - 2326 голов, мелко рогатого скота - 1511 голов, свиней - 1886 голов $[4 ; 5 ; 6]$. Из отраслей животноводства в низкогорье Горного Алтае более всего развито разведение KPC.

На способы содержания КРС, лошадей и MPC населения Республики Алтай оказали влияние территориальные различия горного региона. Проявляющиеся в уменьшении из состава земельных угодий доли сенокосов и увеличении доли пастбищ при переходе от пояса низкогорий к высотным поясам среднегорий и высокогорий. В целом площадь растительных группировок, определенных пастбищами, в низкогорье составляет 44 тыс. га. Из них на долю лесных типов приходится 78\%, луговых - 19\%. В пределах лесостепного ландшафта под выпас домашних копытных используются степные группировки южных и юго-западных склонов (менее 3 \% общей площади пастбищ). Наибольшие площади занимают пастбища по березово-осиновым и березовым лесом, осиново-пихтовой в черневой тайге, а также по сосновым и сосново-березовыми лесам, локализующиеся близ р. Бии (Бия-Ишинский район) [8, с. 24].

На основе анализа природно-климатических условий и земельных угодий Горного Алтая можно отметить, что в низкогорье региона содержание КРС, МРС и лошадей возможно только пастбищно-стойловым способом - когда травоядные копытные в теплое время года выпасается на пастбищах, а с наступлением холодного периода содержатся стойловым способом.

Подробнее опишем стойловое содержание домашних копытных в регионе. Во время наших полевых исследований информанты рассказали, что стойловое содержание КРС и МРC, начинается, когда выпадет снег, обычно, это в октябре, реже из-за теплой осени или за- держки снегопада в ноябре. В холодный сезон животные находятся в хозяйственных постройках (срубные постройки, сараи, навесы и т.д.), возведенных на участке прилегающих к хозяйскому дому. Стойло очищается от навоза два раза в день, также регулярно убирается снег со стога сена.

Во время наших полевых исследований информанты рассказали, что за один годичный период стойлового содержания в среднем одна корова съедает около 30 центнеров (ц.) заготовленного сена. КРС в день кормят три раза. В селах низкогорья в холодное время года, домашних копытных поят из источников, которые находятся в окрестностях поселений. Животные приучены, как самостоятельно идти к месту водопоя, или их туда отгоняют хозяева, для животных часто во льду водоемов прорубают проруби. Воду из проруби достают ведрами. Если в хозяйстве имеется вода с центрального водопровода или со скважины, тогда поение осуществляют с этих источников $[12 ; 2 ; 16]$.

Коров доят два раза утром и вечером. Во время дойки многие хозяева своих коров подкармливают пойлом - это вода с кормовыми добавками, состоящая в основном из овощных очисток обычно картофельных, свекольных, морковных перемешанных с комбикормом и остатками хлеба [24; 20]. Встречаются случаи, когда коровы позволяют себя доить только после того как получат свою часть пойла $[11 ; 12 ; 13]$.

Население низкогорья Горного Алтая КРС выращивают для получения молока, молочных продуктов и качественной натуральной говядины. В беседе информанты отмечали, что из молока изготовляют сметану, творог, в некоторых семьях даже сыры. Для мяса обычно забивают молодых особей в основном годовалых бычков или телок, так как в этом возрасте у животных наиболее нежное мясо $[14 ; 15]$.

На сегодняшние дни для многих хозяйств КРС, служит надежным источником денежных доходов, вырученных от сдачи скота коммерсантам «живым» весом. Например, в некоторых случаях скот сдают в августе месяце, что бы подготовить школьников и студентов к учебе. Так, в 2020-х гг. в среднем одна голова полуторагодовалой телочки или бычка стоила 25-30 тыс. руб. [11; 16].

Население изучаемых районов, овец и коз выращивают ради мяса и молока. Если овец содержат только для мяса, то коз еще и доят. Надо отметить, в 2010 гг. в регионе все больше семей стали разводить коз молочных пород. Это тенденция связано с тем, что на коз идет меньше затрат кормов, чем на коров. Так, за холодный сезон одна голова МРС употребляет 5 ц. сухого сена [16; 19].

В связи с тем, что в 2000-х гг. в Республике Алтай 
предприниматели хорошо скупали лошадей (живым весом), поэтому многие хозяйства низкогорья перешли на разведение коней. Например, в 2020 г. в среднем за одну лошадь выручали 35-40 тыс. руб. [11; 16]. Так же в местах, где развит туризм, местное население держат коней специально для конных прогулок туристам. Например, информанты из сел Иогач и Артыбаш (данные села находятся на берегу живописного Телецкого озера, где в этих местах очень развит туризм), в нашей беседе рассказали, что они держат лошадей только для катания туристов, в среднем одно животное в день приносит прибыль 2-3 тыс. руб. [18; 22].

В низкогорье Горного Алтая лошади на пастбищах пасутся дольше КРС. Так, с наступлением холодов кони свободно пасутся на пастбищах (тебёневка). Затем, когда снежный покров увеличивается, и кони не могут добывать корм (обычно к декабрю или январю), животных полностью переводят на заготовленное сено. За холодный сезон в среднем одна лошадь поедает 30 ц. сена [11; $16 ; 22]$.

С середины весны, когда в низкогорье Горного Алтая сходит снег, и земля немного просыхает, первыми пастись выпускают лошадей. Затем, когда появляется достаточное количество молодой травы, начинается выпас КРС и МРС. Обычно скот весь теплый сезон пасется В окрестностях населенного пункта. На ночь КРС и МРС приходят в село, где с дойных животных получают молоко. А лошади уходят на свободный выпас за ними хозяева только присматривают [11].

Весной КРС, кони и МРС в низкогорье региона пасутся на пастбищах по склонам южной экспозиции и суходольных лугах. Но состояние травяной растительности в начале пастбищного содержания обычно бывает таким, что КРС и МРС еще не могут добыть достаточного корма. Поэтому дома животных обязательно подкармливают сеном, которое осталось с зимы. Достаточно корма на пастбищах появляется к середине - второй половине мая. Летом в низкогорье Горного Алтая скот пасется в лесных пастбищах и заболоченных низинных лугах. Ближе к осени, как заканчивается заготовка сена, животные начинают пастись в отавах. На выпасе стадо находится с раннего утра и до вечера $[8$, с. $181 ; 12]$.

Население низкогорья Горного Алтая также ради мяса и сала разводят свиней. Сало консервируют, солят, маринуют и коптят. Главными достоинствами этих животных является, что они быстро набирают вес, неприхотливы в содержании. В целом это всеядное животное, питается практически любой растительной и животной пищей, а также отходами со стола своих хозяев. Обычно свиней содержат в подворье в небольших помещениях свинарниках $[14 ; 16]$.
В 2000-х гг. распространенным типом свиней в регионе остаются местные беспородные. В наши дни люди часто весной покупают поросят породы ландрас, затем их кормят до осени шесть или девять месяцев и забивают. Так как полугодичные ландрасы в весе не уступают одногодичным местным свиньям. Чаще всего свиней забивают в ноябре месяце, когда наступают холода и мясо животного можно хранить в замороженном виде. Обычно приготовленное на зиму мясо (так же мясо КРС и домашней птицы) сельское население Республики Алтай хранит в пристроенных к дому кладовках или сенях дома $[14 ; 16]$. Так же свиней забивают, когда появляется нужда в деньгах. Например, если нужно подготовить детей в школу, то в этом случае свиней хозяева колют и мясо продают соседям и односельчанам. В 2020 г. свинину в селах изучаемых районов продавали за 250-300 руб. за 1 кг [14; 18].

В хозяйствах низкогорья региона из домашних птиц в основном разводят кур для получения яиц и мяса. Меньше держат гусей, уток и индеек. Например, в 2019 г. в Чойском районе проживало 8192 чел., они выращивали домашних птиц - 3400 гол. [6]. Птиц кормят зерновыми, комбикормами, а также им скармливают сырые или отварные овощи и пищевые отходы. В целом их рацион питания зависит от сезона. Например, летом утки и гуси много времени проводят на пастбищах, питаясь зеленой травой. На зиму оставляют обычно одного гусака или селезня и пару уток или гусынь. Птиц чаще всего забивают в ноябре. Для хранения на зиму тушки птиц замораживают [23].

Низкогорье Горного Алтая имеет немалый потенциал в плане пчеловодства. Здесь мёд, в основном, собирается с дикоросов: желтая акация, жимолость, черная смородина, малина, кипрей, дягиль и другие медоносы являются превосходной медоносной базой.

Первые весенние работы на пасеке начинаются непосредственно после выставки пчел из зимовника. Место для улья выбирают крайне внимательно. Оно должно быть сухим, защищенным от ветров, удалено от построек с другими животными, жилых помещений и проезжих дорог. Примерное расстояние между ульями составляет 1 или 1,5 м что, делается, чтобы пчелы не потеряли ориентир и возвращались в свои домики. Также домики красят в разные цвета, чтобы облегчить насекомым задачу поиска именно своих ульев. При подлете к пасеке медоносная пчела лучше распознаёт свой улей по окрашенному цвету [9; 10].

Первый - весенний мёд идет с вербы и одуванчика, так в нашей беседе информант рассказал: «Как только верба зацвела они (пчелы) начинают таскать мёд в улей» [9]. В июне мёд уже собирается с различных цветов и цветущих растений. Но главный медосбор приходится 
на июль-август. Ценность мёда Горного Алтая заключается в том, что он собран с разнотравья. Поэтому, особой популярностью в регионе и по всей России пользуются именно полифлерный мед, или смешанный (сборный) цветочный продукт, который пчелы собирают с различных растений горного региона. Многие растения являются не только прекрасными медоносами, но и лекарственными, встречающимися лишь на территории региона и близлежащих районах [10].

По окончании периода медосбора, который характеризуется прекращением лета, производится отбор излишков меда из ульев. Рекомендуется отбор меда совершать после того, как пчелы запечатают последние рамки.

На зиму обычно пчелосемьи консервируют в омшанике, в качестве которого приспособлено какое-нибудь строение. Пчелы на зиму сбиваются в шар, в центре которого находится матка, и поддерживают в нем постоянную теплую температуру [9; 10$]$.

Пчеловодство в 1990-е-2000-ые гг. активно развивается на территории Республики Алтай. Увеличилось число как любительских, так и профессиональных пасек. В начале лета 2020 г. в г. Горно-Алтайске 1 л мёда из разнотравья стоил 300-400 руб., а 1 л дягилевого мёда - 1000 руб. [10]. Из продуктов пчеловодства, кроме мёда, популярностью пользуются воск, перга, прополис, пчелиное маточное молочко. Эти продукты принимают участие в обменных процессах, обеспечивают организм человека энергией, повышают иммунологические процессы, оказывают положительное влияние на профилактику и лечение многих заболеваний.

Таким образом, на начало XXI века в системе жизнеобеспечения населения низкогорья Горного Алтая животноводство играет важную роль. В исследуемом регионе природно-климатические условия наложили свои черты на содержание животных. Здесь КРС, МРС и лошадей выращивают только пастбищно-стойловым способом. В подворье местного населения разводят свиней и домашнюю птицу.

В рассматриваемый период животноводство остается одним из источников денежных доходов. Например, часть денежных средств население низкогорья получают от реализации скота, как в живом весе, так и от продажи мяса забитого животного. В местах, где развит туризм, местное население держат коней для конных прогулок туристов.

Также на изучаемых массивах региона развито и пчеловодство. Из продуктов пчеловодства кроме мёда, популярностью пользуются и сопутствующие продукты это воск, перга и прополис.

ЛИТЕРАТУРА

1. Алтайцы: Этническая история. Традиционная культура. Современное развитие/ редколл. Н.В. Екеев (отв. ред.), Н.М. Екеева, Э.В. Енчинов; НИИ алтаистики им. С.С. Суразакова. - Горно-Алтайск, 2014. - 464 с. + 3 цвет. вкл.

2. Вербицкий В.И. Алтайские инородцы. Сборник этнограф. ст.; репринт. изд. - Горно-Алтайск: Ак-Чечек, 1993. - 272 с.

3. Гельмерсен Г.П. Телецкое озеро и телеуты восточного Алтая [Электронный ресурс]. 2020. URL: http://vital.lib.tsu.ru/vital/access/manager/Repository/ vtls:000634408 (дата обращения: 22.06.2021).

4. Инвестиционный паспорт муниципального образования «Майминский район» Республики Алтай [Электронный ресурc]. URL: https://maima-altai.ru (дата обращения: 22.06.2021).

5. Инвестиционный паспорт муниципального образования «Турочакский район» [Электронный ресурc]. URL: https://turochak-altai.ru (дата обращения: 22.06.2021).

6. Инвестиционный паспорт муниципального образования «Чойский район» [Электронный ресурc]. URL: http://www.чойский-район.pф/Administraciya/ ieco25-1-20.pdf (дата 0бращения: 22.06.2021).

7. Кандаракова Е.П. Обычаи и традиции чалканцев. - Горно-Алтайск: Изд-во «Республиканская Горно-Алтайская типография», 1999. - 176 с.

8. Макошев А.П. Вопросы территориальной организации горно-животноводческого хозяйства Алтая: монография. - Горно-Алтайск: РИО ГАГУ, 2010. 264 c.

9. НА НИИА. МНЭ (Научный архив Научно-исследовательского института алтаистики им. С.С. Суразакова. Материалы научной экспедиции). Дело (Д.) № 156. [Жужков В.А. 1963 г. р.].

10. НА НИИА. МНЭ. Д. № 156. [Романенко У.С. 1992 г. р.].

11. НА НИИА. МНЭ. Д. № 178. [Бедарев А.Н. 1974 г. р.].

12. НА НИИА. МНЭ. Д. № 178. [Стенина А.А. 1973 г. р.].

13. НА НИИА. МНЭ. Д. № 178. [Сыщенко П.П. 1973 г. р.].

14. НА НИИА. МНЭ. Д. № 198. [Галанов А.В. 1983 г. р.].

15. НА НИИА. МНЭ. Д. № 198. [Жандарикова Т.0. 1978 г. р.].

16. НА НИИА. МНЭ. Д. № 198. [Тандыков Н.В. 1951 г. р.]. 
17. НА НИИА. МНЭ. Д. № 198. [Тебеков В.Т. 1967 г. р.].

18. НА НИИА. МНЭ. Д. № 198. [Тудашев Н.М. 1961 г. р.].

19. НА НИИА. МНЭ. Д. № 198. [Фефилов В.Б. 1961 г. р.].

20. НА НИИА. МНЭ. Д. № 198. [Хорняк В.П. 1971 г. р.].

21. НА НИИА. МНЭ. Д. № 198. [Чернов С.И. 1976 г. р.].

22. НА НИИА. МНЭ. Д. № 198. [Чугулов С.П. 1999 г. р.].

23. НА НИИА. МНЭ. Д. № 198. [Чунжекова Л.С. 1939 г. р.].

24. НА НИИА. МНЭ. Д. № 198. [Эдокова А.А. 1979 г. р.].

25. Назаров И.И. Кумандинцы: традиционное хозяйство и материальная культура : монография / И.И. Назаров; отв. ред. Н.А. Томилов; АлтГУ, Ист. фак., Каф. археологии, этнографии и музеологии. - Барнаул: [6. и.], 2013. - 192 с.: ил.

26. Национальный состав и владение языками, гражданство: Стат. Сборник Алтайстат. - Горно-Алтайск, 2013. - 419 с.

27. Радлов В.В. Из Сибири. Страницы дневника / пер. К.Д. Цивиной и Б.Е. Чистовой; коммент., послесл., ред. С.И. Вайнштейна. - М.: Наука, 1989. - 749 с.

28. Сатлаев Ф.А. Кумандинцы: (Историко-этнографический очерк XIX - первой четверти XX века). - Горно-Алтайск: БУ РА Литературно-издательский Дом «Алтын-Туу», 2016. -200 c.

29. Тюркские народы Сибири / Институт этнологии и антропологии им. Н.Н. Миклухо-Маклая РАН; Омский филиал Института археологии и этнографии СО РАН; отв. ред. Д.А. Функ, Н.А. Томилов. - М.: Наука, 2006. - 768 с.

30. Швецов С.П. Репринтное воспроизведение издания «Горный Алтай и его население. Кочевники Бийского уезда». - Барнаул, 1900. - Горно-Алтайск: Издво «Ак Чечек», 2008. - 571 c.

31. Шитова Н.И. Русские низкогорной зоны Горного Алтая (20 - начало 21 вв.). - Горно-Алтайск: РИО ГАГУ, 2014. - 208 с.

32. Ядринцев Н.М. Сибирские инородцы, их быт и современное положение. - СПб., 1891. - 310 с.

(c) Енчинов Эркин Валериевич (enchinov_e@mail.ru), Торушев Эркем Геннадьевич (erktor@mail.ru).

Журнал «Современная наука: актуальные проблемы теории и практики»

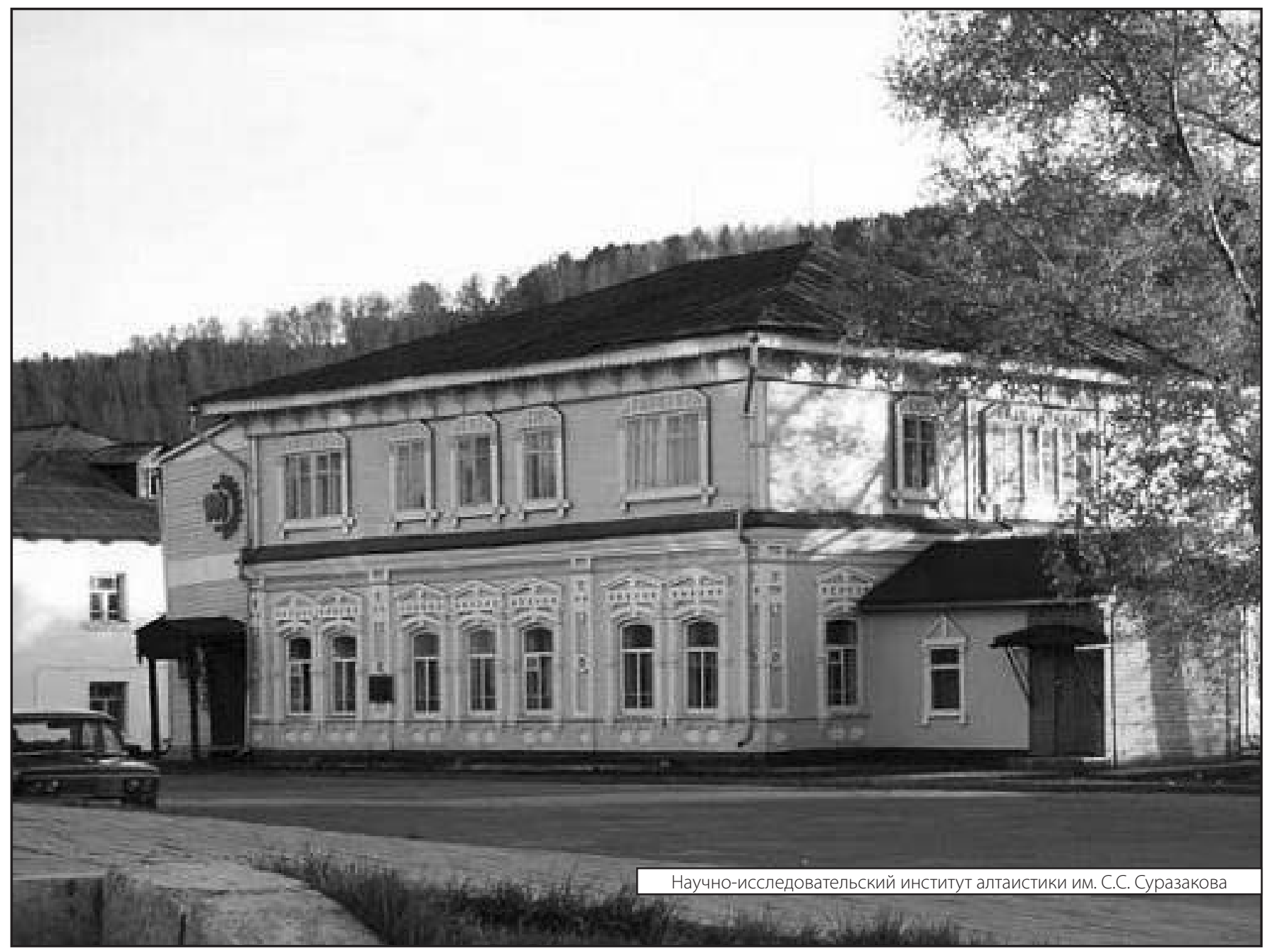

